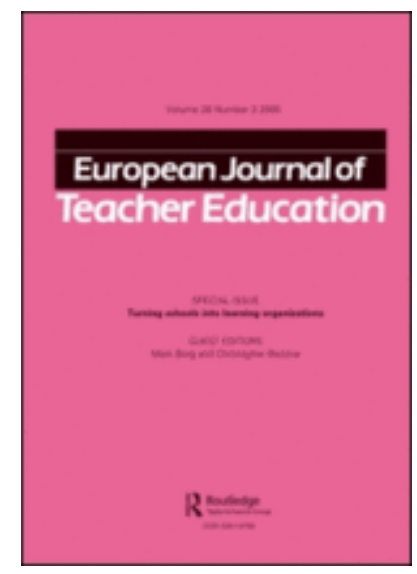

\title{
The Change in Pre-service Primary Teachers' Possible Selves in Relation to Science Teaching
}

\begin{tabular}{|r|l|}
\hline Journal: & European Journal of Teacher Education \\
\hline Manuscript ID & EJTE-2019-0343.R2 \\
\hline Manuscript Type: & Original Article \\
\hline Keywords: & $\begin{array}{l}\text { Possible selves, Preservice primary teacher, Narrative analysis, Teacher } \\
\text { identity, Science Education }\end{array}$ \\
\hline \multicolumn{2}{|l}{} \\
\hline
\end{tabular}

\section{SCHOLARONE ${ }^{m}$ \\ Manuscripts}




\title{
The Change in Pre-service Primary Teachers' Possible Selves in Relation to Science Teaching
}

\author{
Anne Pellikka, Faculty of Education, University of Oulu, Finland \\ Sonja Lutovac, Faculty of Education, University of Oulu, Finland \\ Raimo Kaasila, Faculty of Education, University of Oulu, Finland
}

\begin{abstract}
This study examines pre-service primary school teachers (PSTs) possible selves in relation to science teaching and the ways in which these possible selves change over time. This longitudinal study adds to the body of knowledge by examining PSTs' possible selves at various time points throughout their teacher preparation: three PSTs, selected from a wider sample, were interviewed three times about their future aspirations as science teachers. Narrative analysis was applied to show the changes in three PSTs' possible selves in response to the science methods course and teaching practicum. PSTs articulated general, collective and specific hoped-for and feared possible selves. Our findings highlight the changes in the possible selves that pertain to their cognitive and affective dimensions and occurred in different stages of teacher education. These changes were significant for the development of PSTs' identity. The implications of these findings are discussed in the context of science teaching.
\end{abstract}

Keywords: possible selves, teacher identity, science education, pre-service primary teacher, narrative analysis 


\section{Introduction}

It has been suggested that the process of becoming a teacher involves retrospective and future-oriented activities (Avraamidou 2019; Carrier, Whitehead, Walkowiak, Luginbuhl and Thomson 2017; Hamman, Gosselin, Romano and Bunuan 2010; Lutovac and Kaasila 2014; Pellikka, Lutovac and Kaasila 2018). For example, research literature recognises the effects of the socio-historical past on pre-service primary school teachers' (PSTs') identity development (Lutovac and Kaasila 2012, 2014; Pellikka, Lutovac and Kaasila 2018; Furlong 2013). These studies highlight that PSTs' memories from their time at school influence their beliefs of what teachers and teaching should be like. Furthermore, to create a realistic, yet positive teacher identity in the context of science teaching, PSTs should also become aware of their identity goals, such as their hopes and fears for future science teaching as these can shape their teaching (Hamman et al. 2010; Hong and Greene 2011; Lutovac and Kaasila 2014; Markus and Nurius 1986).

Regarding a future perspective in one's identity development, the construct of possible selves has been widely applied. Possible selves have been used significantly in psychological research (Cross and Markus 1991; Markus and Nurius 1986; Oyserman and Markus 1990) and have been defined as what someone would like to be or is afraid of becoming. Thus, they represent individuals' hopes and fears for the future, i.e. 'they are selves to be approached or avoided' (Markus and Nurius 1986, 954). A few studies have been conducted in an educational context, mostly to investigate teachers' development (Hamman et al. 2010; Hamman, Wang and Burley 2013b; Hamman, Coward, Johnson, Lambert, Zhou and Indiatsi 2013a; Lutovac and Kaasila 2014). On the other hand, the application of possible selves in the context of science teaching is scarce (Hong and Greene 2011). 
Teacher identity development in the phase of teacher education has been studied, but there is still much to learn about the process (e.g. Flores 2020). Teacher change is central in teacher identity development, but we also know it is a difficult process (DarlingHammond, Hyler and Gardner 2017; Tam 2015) and research shows that the influence of teacher education on the process of shaping PSTs' identities is not as strong as it is that of personal experience (Ruohotie-Lyhty and Kaikkonen, 2009; Hong and Greene 2011). Therefore, a better understanding of how teacher identities develop and can be shaped in various courses during teacher preparation is needed. We are especially interested what kind of changes regarding PSTs' identities can be induced in a relatively short period of time, such as for example, as a result of a single course.

In this study, we examine PSTs' future-oriented teacher identity development in science education context and via the construct of possible selves (Markus and Nurius 1986). While we know that possible selves are dynamic and changeable, most examinations of teachers' or PST' possible selves have been investigated from a more static viewpoint, i.e. at one point in time. Therefore, this study contributes to the body of knowledge by examining PSTs' possible selves at three time points throughout their teacher preparation: before and after the environmental studies course and after the teaching practicum. This approach will account for the process of identity development and the ways science teacher education may stimulate this process. Our guiding research questions are: 1) What are pre-service primary school teachers' hoped-for and feared science teacher possible selves? and 2) What kind of changes in pre-service primary teachers' possible selves can be observed at different points in time, i.e. as a response to the environmental science course and teaching practice? 


\section{Theoretical Framework}

\section{Possible Selves}

Possible selves, originally introduced by Markus and Nurius (1986), are individuals' future identity expectations. They stand for what kind of persons individuals want to be in the future and what it is possible for them to strive towards, and, as such, they reflect and provide an evaluative context for what kinds of characteristics the individual has currently (Markus and Nurius 1986; Oyserman and Leah 2011; Oyserman and Markus 1990). For this reason, possible selves' function as incentives for individual behaviour and guide the actions individuals take (Cross and Markus 1991; Markus and Nurius 1986), as well as self-regulation (Hamman et al. 2010; Hamman et al. 2013b).

Possible selves are representations of what someone would like to become (hoped-for self) or what someone is afraid of becoming (feared self). This means that the hoped-for selves are those selves that PSTs strive towards, such as, becoming 'an inspiring teacher', and feared selves are those that PSTs try hard to avoid, such as becoming 'a boring teacher'. It has been noted that the balance between hoped-for and feared selves in the same domain describes how motivated individuals are in terms of achieving their future selves (Oyserman and Markus 1990; Oyserman, Bybee, Terry and Hart-Johnson 2004). Therefore, if the hoped-for self is balanced against the feared self in the same domain, it is thought to disclose individual motivation for achieving his or her goal (Hamman et al. 2013a; Oyserman and Markus 1990; Oyserman, Bybee and Terry 2006). On the other hand, the temporal distance and how near or far away possible selves are in the future will influence individuals' motivational strivings, e.g. students might consider their possible selves to be real only after graduation, meaning that not much can be done yet to achieve their future goal (Henry 2015; Oyserman and Leah 2011). Also, the experience of excessive ease or difficulty when considering the future self may be thought to require 
no current actions (Oyserman and Leah 2011). Similarly, vague or general possible selves do not guide self-regulative actions since they lack a precise strategy of how to reach or avoid future selves (Oyserman et al. 2004).

Possible selves are sensitive to change (Cross and Markus 1990; Markus and Nurius 1986, 956). They can change with respect to self-discrepancy between an individual's actual and ideal self, i.e. possible selves can be adjusted to narrow the gap between real and ideal (Higgins 1987). This re-evaluation of possible selves can be upward or downward and is elicited by salient events, experiences and feedback relating to the development of prevailing skills (Carroll, Shepperd and Arkin 2009; Henry 2015). The evaluation of possible selves may help individuals to explore the relation between their own self-view and the demands of the new roles (Ibarra 1999). Previous literature on pre-service teachers' possible selves suggests that they do not just occur independently from each other, but rather 'comprise the matrix of a new teachers' agenda for self-construction' (Hamman et al. 2013b, 231). PSTs' possible selves can also be either task-focused, reflecting instruction or classroom management, or quality-focused, reflecting the quality of the self as a teacher (Conway and Clark 2003) and they can be influenced by the context, relationships and cooperating teachers (Hamman et al. 2013a).

\section{Possible Selves in Teacher Education Research}

Possible selves have been investigated in various teacher education contexts. For example, pre-service science teachers have shown that their possible selves are equally concerned about cognitive issues, such as content knowledge and supporting students to develop their knowledge, and affective issues, such as effective teaching and the caring role of teachers (Hong and Greene 2011). Also, the pre-service English teachers' desired 
selves were found to be based on their feelings of competence on subject matter knowledge, both desired and feared selves were connected to either feelings of competence or insecurity related to subject matter (Brady 2019). Lutovac and Kaasila (2014) revealed that in the context of mathematics teaching pre-service primary teachers' possible selves can be either decisive (goal-oriented and balanced with emphasis on selfdevelopment) or irresolute (lacking goals, imbalanced and uncertain regarding the future) in terms of their motivation to take self-development actions. Also, Dabback (2017) reported that the pre-service music teachers have positive possible selves as successful music teachers that are achievable with reasonable efforts, which is somewhat similar to the findings of Lutovac and Kaasila (2014) of decisive possible selves. However, Dabback (2017) reported also pre-service music teachers' feared selves that were related to doubts of not being able to transition to music instructor and fears of not fulfilling the others' expectations, which again bear similarities to the irresolute possible selves (Lutovac and Kaasila 2014). Therefore, based on previous literature on pre-service teachers' subject specific possible selves, we can conclude that they often concern competence in the subject in question, concern both internal and external expectations of an individual PST and they show different levels of motivational aspects for future. That said, there seems to be a paucity in research on pre-service primary teachers' possible selves in the context of science teaching.

\section{Teacher Identity and Change in the Context of Science Teaching}

In this study, teacher identity is seen 'as ongoing process of interpretation and reinterpretation of experiences; implying both person and context; consisting of subidentities; for which agency is central' (Beijaard, Meijer and Verloop 2004, 122). We consider pre-service primary teachers who teach around 10 different subjects, such as 
mathematics, mother tongue, science, etc. As generalists, they have various subjectrelated teacher identities, whereas science teaching is one among those. Therefore, we use here the term teacher identity in the context of science teaching, rather than science teacher identity. In the similar line, Gunning and Mensah (2011) note that pre-service primary teachers might have limited science content knowledge, science pedagogical content knowledge, inquiry practices, scientific literacy, and self-efficacy with science teaching. They also might have contradictory views of science teaching and do not desire to become a science teacher (Mensah 2016).

Additionally, we find Avraamidou's (2014) understanding of science teacher identity useful. The author suggested that science teacher identity should be viewed 'as a process instead of a product and focus our attention on examining the pathways through which teachers form their identities - the processes of identity development' (166). Essential in this process is that PSTs engage in the cognitive development of theories and practices of science teaching to successfully assimilate them into their teacher identities (Woolhouse and Cochrane 2015). Therefore, becoming a reform- and inquiry-oriented science teacher is not simply acquiring a new set of knowledge and skills, but rather, it is the process of developing a professional identity (Bryce, Wilmes and Bellino 2016; Naidoo 2017).

Arguably, teacher identity development and teacher change are related processes: teacher identity development often leads to changes in PSTs' knowledge and beliefs about teaching and teaching practices (Boyle, While and Boyle 2004; Fullan 2014) and thus, we can also speak of teacher change (Clarke and Hollingsworth 2002; Kaasila and Lauriala 2010; Darling-Hammond et al. 2017; Tam 2015). Moreover, teacher identity includes and is influenced by possible selves. Oyserman and Leah (2011) talk about connection between teacher identity and possible selves since individuals are motivated to act towards those goals that feel congruent with their current identities. We 
acknowledge also that PSTs' future-oriented professional identity development through possible selves builds on PSTs' prior experiences with their school time as well as on experiences with university teachers and mentors in teacher training schools (Ronfeldt and Grossman 2008; Urzua and Vasques 2008).

\section{Methods}

\section{Data Collection}

The context of our study was the primary teacher education unit in one Finnish university. In this context, the PSTs go through a 5-year primary school teacher education programme from which they graduate as primary teachers (with a Master of Education) for grades 1-6 for students between the ages of 7 and 12 years old. These teachers are considered to be generalists, because they teach various school subjects, without the specialisation in any particular subject. During the first year of their teacher education studies they participate in a science method course, Environmental Studies I (ES), which includes the inquiry-oriented didactics of biology and geography. Two years after the science method course they have their first teaching practicum. The main goal of the practicum was to learn to plan and implement teaching in different subjects, including science, with varying methods. The first author of this study is the teacher of the ES course, and thus shares immediate pedagogical relationship with the participants. Hence, the participants were assured that their participation in the study will bear no influence on their evaluation in the course nor their progression in the studies. On the contrary, they were encouraged to reflect upon the participation in the research as an opportunity for their initial professional development. The students provided a written consent for the participation in the study. 
The participants in this study were three (3) first-year PSTs who were chosen from a wider sample of 41 PSTs'. The data collection procedure is displayed in the Figure 1. For ensuring the validity of the data we have collected two different kinds of data, questionnaires and interviews. All participants $(n=41)$ answered questionnaires before (Q1) and after (Q2) the ES course (see Appendix 1.). The preliminary analysis of Q1 revealed that PSTs had differing backgrounds related to their memories of science studies from their time at school (see also Lutovac and Kaasila 2014; Avraamidou 2019; Miller and Shifflet 2016), and based on this phase we decided to invite to the interview (Int1) 11 students with the most differing backgrounds related to biology and geography teaching and learning, i.e. those that reported the most positive, negative and neutral memories in the first questionnaire (Q1). These 11 PSTs also responded to the questionnaire $2(\mathrm{Q} 2)$ and were interviewed after the course (Int2).

Two years after the science methods course, we conducted another interview to account for the possible changes that PSTs might have undergone as a result of teaching practicum. At that point, three PSTs responded to the invitation to the third interview (Int3). Coincidentally, these participants also represented the negative, neutral and positive memories about biology and geography (for Int2 and Int3 see Appendix 1.). Our interview procedure was an open-ended thematic interview (Cohen, Manion and Morrison 2002). During the interviews, participants were not directly asked about their possible selves; instead, they were encouraged to tell about their beliefs and experiences, also regarding their future, as freely as they wanted (cf. Hamman et al. 2010; Markus and Nurius 1986; Oyserman et al. 2004).

Figure 1. near here. 


\section{Data Analysis}

We chose narrative analysis for the method of our study, since identity has been understood to be constructed through stories individuals tell about their lives (Beijaard et al. 2004; Polkinghorne 1995). We also build on Clandinin and Connelly $(2000,20)$ who define narrative research as 'a way of understanding experience'. At first, the interviews (In1-Int3) were transcribed by the first author. Then she read the whole data, including Q1-Q2 and Int1-Int3, several times to be able to detect all parts addressing PSTs' possible selves. Based on this holistic reading (Lieblich, Tuval-Mashiach and Zilber 1998), the first author extracted all the data regarding each participants' possible selves. Second, all authors re-read the extracted data individually to produce agreement on understanding of the change in possible selves at different points in time. After detecting the changes in possible selves, we were able to conduct explanatory, emplotted narratives of the participants' possible selves (Polkinghorne 1995).

To emplot the narratives based on the extracted data, we first identified the outcomes of each narrative (Polkinghorne 1995; Kaasila 2007). We noticed that the three PSTs - Nina, Kaarina and Tomas - had different hoped-for and feared possible selves after their teaching practicum. We continued the process by accounting for the situation at two earlier points in time, before the course and after the course. We tried to trace a point in which the change occurred, along with what facilitated the change. Therefore, the emplotted narratives include explanation for the changes in PST' possible selves. In particular, we focused on explicating the role of the course and teaching practicum in the changes that occurred in PSTs' possible selves. In the final step, all the extracted data and explanations were ordered chronologically. In the results section, we present three preservice teachers'-Nina's, Kaarina's and Tomas'-emplotted narratives. For ensuring the validity of data analysis we have applied researcher triangulation. All the authors read 
the extracted data and formed preliminary interpretations. The authors then discussed about these interpretations, and in case of disagreement, negotiated to reach a consensus on the final interpretations.

\section{Results}

\section{Nina}

Nina had reluctant beliefs about biology and geography at the beginning of the ES course. Although she can explain her emotions relating to these subjects, she is incapable of explaining why she has such distressing feelings regarding them:

It is a time for self-study with my own attitude, for some reason I still feel like "no", kind of reluctant (when discussing about biology). For some reason, when there is a discussion about biology and geography, I start to get anguished about everything I do not know. I wonder where my attitude derives from. (Int1)

Because of her above-mentioned background, Nina's science teacher possible selves are closely linked to disposing of her unenthusiastic feelings at the beginning of the ES course:

I would like to shake off my prejudice about these subjects ... (Q1) ... I should have a different kind of attitude ... I would kind of like to break those conceptions that I have. (Int1)

Nina's feared selves are likewise firmly linked to her own reluctant beliefs towards the subjects, and she also fears passing on this feeling of indifference: 
I do not want my teaching to be boring and dull so that it will not cause the same attitude in others (students) and also, that I accidentally pass on that attitude to others, that this (biology) is nothing, and we can do it with our left hand. (Int1)

After the ES course, Nina told how her beliefs started to change and how she was motivated to learn more and had set an objective for herself:

... And I have become more interested, and I would like to know more about these things and learn. ... I would like to kind of patch up my knowledge. (Int2)

During the ES course, Nina's concerns of passing on her own reluctant attitude changed, and she hoped for the opposite.

... I would like to pass on a kind of positive attitude regarding these subjects, so that I can wake up their interest in the surrounding world... (Int2)

In addition to her persistent fear of passing on the wrong kind of attitude, Nina's feared self took the form of an incompetent teacher after the ES course:

Fear of not becoming a good enough teacher and not being able to face the upcoming challenges (Q2). I would not like to depreciate these subjects ... On no account do I wish to pass this attitude on to students. (Int2)

Two years after the ES course, after the first teaching practicum, Nina's comprehension of the subjects had changed. She now acknowledged the multifaceted nature of the subjects, which turned her hoped-for self towards being an expert. Her hoped-for science teacher self was also strongly embedded in being an inspiring teacher:

So, what has changed is that I realise now how versatile these subjects are, it is a challenge. ... I hope that I will someday become good at them. In the future, I would 
like to be a teacher who is acquainted with the topics and is an expert. I would like to be inspiring, and I would like to pass on that interest and true enthusiasm. (Int3)

Nina's feared selves changed from passing on the wrong kind of attitude to passing on misconceptions, and this balances against her desire to be an expert:

... I wish that I could feel confident about the contents that I have to teach so that I will not pass on any misconceptions. (Int3)

Overall, Nina's possible selves revolved around her own attitude. Through her hopes and fears for the future, she knew what she needs to do to accomplish her possible self. Her science teacher identity development was successful since she could formulate clear goals, like changing her beliefs and patching up her knowledge, based on her futureoriented possible selves.

\section{Kaarina}

Kaarina had very positive beliefs especially towards biology. She said how she had enjoyed learning biology and how she is good at it. Also, Kaarina ascended her own biology and geography teacher as the protagonist of her retrospective and future-oriented identity development (also see our previous study: Pellikka, Lutovac and Kaasila 2018). This delineates her entire science teacher identity development:

As a learner (of biology), I have been relatively good, I got the best grade in upper secondary school ... The functions of the human body were easy and nice to learn, and logical. As a teacher, I would like to be like my own biology and geography teacher-lively, inspiring and full of enthusiasm. The kind of teacher who takes everyone into account and answers questions repeatedly. (Q1) 
At the beginning of the ES course, Kaarina's hoped-for science teacher self related to the characteristics of her own biology teacher at school as she would have liked to be passionate, honest and have good content knowledge. She did not mention any feared selves.

I would like to be fair and have passion for my work. In the future, I would like to have good content knowledge and to be honest with my students about what I know and what I don't know, kind of like my teacher in upper secondary school. If someone asked something that she did not know, she used to say that she would check that for the next time. (Int1)

After the ES course, Kaarina wished to give versatile lessons and to be a nonauthoritarian, affective teacher, which again, expressed her wish to be inspiring, reflecting her memories of her own biology teacher:

I hope that my lessons will be versatile and consist of different kinds of elements. (Q2) I would like to be easily approachable ... and kind of inspiring and cheerful, and whose lessons one can enjoy. (Int2)

Kaarina's feared self only appeared after the ES course. She feared of giving repetitive, unvaried lessons, which was the opposite to her hopes:

So that you don't drift to that when all your lessons are similar: open books, (and) go through it chapter by chapter. (Int2)

After the practicum, Kaarina revealed that her mentor teacher in practicum had confirmed that her own interest towards biology was evident and that it carried her as an environmental studies teacher: 
I talked with the class teacher, and it is apparent that one can tell which subjects I am interested in, that I am interested in Environmental Studies and that this subject is so interesting for me. I found that I was good at it, which means that since I am interested, I am an interesting teacher, in a way that the students will also see that I am interested. (Int3)

Therefore, after the practicum, Kaarina's hoped-for science teacher self resembled her own biology teacher again, and she wished to be interesting, inspiring and have good content knowledge. She also wished to be her own self as a teacher:

I would like to be (a teacher) who one can tell is interested in her work, and who the students also feel that maybe knows something about ES. ... I would like to be inspiring and motivated. Somehow being able to maintain my own personality in my work, in a way that I am my own self in my work in a good way. (Int3)

Kaarina's feared self balanced against her hoped-for self after the practicum. It was important for her to be true to herself in her role as a teacher. After the practicum, she again brought forth the same fear of being repetitive in her work as was mentioned after the science method course.

I would not like to perform a certain role. I do not want my work to be numbing, and I do not want to repeat the same things all the time. (Int3)

To summarise, Kaarina's future-oriented possible selves kept returning to her own biology teacher, and she even received confirmation of this aspiration in the practicum. Therefore, her science teacher identity did not display significant future-oriented development, and, after the practicum, her science teacher identity development remained static. 


\section{Tomas}

Tomas had neutral beliefs about biology and geography at school. He only became interested in natural sciences after upper secondary school. He valued the big picture in natural sciences but not so much the small trivia, like species identification:

Both subjects were quite neutral to me throughout my whole school experience, both have nice and boring topics. I became interested in natural sciences only after upper secondary school. (Q1) The most interesting part is the kind of view that is a broad, natural scientific way of observing the Earth as a whole, and not so much about identifying freshwater fishes or lichens. (Int1)

At the beginning of the ES course, Tomas described his hoped-for science teacher self as an inspiring teacher. He was eloquent in his expressions, which revealed that this aim is significant for him as a future science teacher:

But, the kind of teacher I would like to be is one that awakes their curiosity and interest in the topic at hand a bit. ... If I could build that kind of curiosity and thirst for knowledge in those students, I think that would be more important than just listing species. ... I would like to be an inspiring teacher... (Int1)

Tomas feared that he is going to be a boring, indifferent teacher:

So, I would not like to be a boring teacher, whose lessons are only a compulsory thing, through which you have to sit and afterwards you forget all about. (Int1)

After the ES course, Tomas' hoped-for self had changed to an inquiry-oriented science teacher:

I wish I could... have a scientific method or approach or at least aim at that. (Q2) And that I could model that natural scientific method (inquiry). ... that at first, we 
could think about what could happen and then examine and then draw conclusions. (Int2)

He elaborated on his hope to awaken curiosity even further, indicating that he understood the significance of it in science teaching:

To wakening curiosity would be the aim. That would be my personal goal, regardless of the curriculum. The curiosity, so that students would be interested about natural phenomena." (Int2)

After the ES course, Tomas' fears did not relate anymore to what kind of teacher he would like to be but more to how he would like to teach. He now feared becoming only a knowledge-transmitting teacher since he wished to explain the causalities of things:

... It would be central to demonstrate natural sciences to them and make them think about those things. So, it will not be just teaching that things work this way but also thinking about the reasons. (Int2)

After the practicum, Tomas realised the relevance of content knowledge in science teaching. He was confident in giving ES lessons and elaborated on how his hoped-for science teacher was an expert, an inspiring, a demanding and a knowledgeable teacher. However, he did not mention feared selves anymore:

... One should know so much more than the curriculum requires, even though it is not the content that you are teaching to students, you should be able to build up connections. ... you can talk with them (students) in a totally different way if you have the knowledge. So, in that sense, the conception of myself as a teacher changed, and it (the feeling) got stronger in that I can give ES lessons. When you are interested and curious about these things yourself ... it is easy to transfer that 
enthusiasm to students. So, I want to be an inspiring, yet demanding, teacher and be seen as an expert in students' eyes. (Int3)

Altogether, Tomas' possible selves moved from the desire to awaken curiosity towards the desire to be an inquiry-oriented teacher and onward, to having specific content knowledge. Through his possible selves, Tomas disclosed his path of science teacher identity development.

\section{Discussion}

In this paper, we addressed three pre-service primary teachers' possible selves in the context of science teaching and how they changed during the science method course and teaching practicum. In PSTs' narratives, we identified general, collective and specific hoped-for and feared possible selves. In addition, our findings displayed the changes in the possible selves that pertain to their cognitive and affective dimensions and occurred throughout the different stages of teacher education.

PSTs' articulated general and collective hoped-for possible selves of being inspiring and knowledgeable science teachers. Being an inspiring teacher represented the wish to be able to change one's own reluctant beliefs, the wish to be as the ideal teacher from one's own school years and, lastly, the wish to awaken students' curiosity towards science itself. On the other hand, being a knowledgeable teacher was manifested as being an expert, as being knowledgeable in the eyes of students and as being inquiry-oriented. These possible selves of are quite general and may not necessarily motivate the change in actions (Oyserman et al. 2004). However, these general possible selves carried a great personal significance for PSTs' identity development. In addition, our findings suggest that PSTs' possible selves were well balanced: PST' were able to articulate what they hoped for and 
strive towards, but also what they fear and want to avoid. This suggests that motivation for pursuing the hoped-for selves and avoiding the feared selves is, after all, likely to occur (Markus and Nurius 1986; Oyserman and Markus 1990). We believe that the wellbalanced possible selves represented in our findings are enduring and are, thus, likely to be strived for, despite the temporal distance and that these general possible selves do not necessarily require PSTs' change instantly (cf. Henry 2015; Oyserman and Leah 2011).

PSTs also articulated more specific hoped-for and feared possible selves. These too were well balanced and appeared as the opposites. For example, the hoped-for self of shaking off prejudiced beliefs was balanced against the feared self of passing on own prejudice, the hoped-for self of maintaining your own personality was balanced against the fear of performing a role and the hoped-for selves of being inquiry-oriented and a scientific role model were balanced against the fear of being a knowledge-transmitting teacher. These specific possible selves are congruent with the PSTs' current identities (cf. Higgins 1987; Oyserman and Leah 2011), and are also decisive, meaning that they have a strong selfdevelopment orientation (Lutovac and Kaasila 2014). Therefore, we can conclude that PSTs in our study knew what needed to be changed and done to achieve their possible selves, showing the direction for the development of their teacher identity in the context of science teaching.

While research on teacher change during teacher preparation is vast, our findings contribute significantly to the understanding of the changes in PSTs' possible selves in the context of science teaching, as well as more broadly. We consider these changes as essential for understanding and assisting the processes of teacher identity development and teacher change during teacher preparation (see e.g., Kaasila and Lauriala 2010; Korthagen 2017; Tam 2015). The findings of our study demonstrated that the change can occur in both cognitive and affective dimensions of possible selves (Hong and Greene 
2011), and that the change in possible selves can be characterized as upward or downward (Henry 2015; see also Carrol et al. 2009).

The clear upward change was induced during the science method course, as the wish to have more content knowledge changed to the more profound wish to be an expert, i.e. to understand what should be known and how it should be enacted as a teacher. This upward change in cognitive dimension of possible selves also displays how the future-oriented teacher identity development is deepening, rather than broadening. On the other hand, the downward change seemed to have been induced during the teaching practicum. The wish to be an inquiry-oriented teacher changed to the wish of having a larger knowledge base. We consider the latter as a downward change since inquiry-oriented teaching is preferred in science education (e.g. Woods-McConney et al. 2016). However, because PSTs need a strong knowledge base in order to conduct inquiry-oriented lessons, we see this change in possible selves could also be interpreted as PSTs' feeling the need for self-development in this aspect (Bryce et al. 2016; Naidoo 2017). The changes identified in this study, therefore, are significant as they highlight that the learning experiences, such as the science method course and the practicum, have the power to revise PSTs' possible selves (Henry 2015; Ibarra 1999). This finding challenges Hong and Greene's (2011) observation regarding the limited influence of teacher education on student teachers' possible selves compared to long-lasting memories from school. We hence argue that teacher education, including science method courses and practicums, may have a significant influence on how PSTs learn to assess their own needs and development in the context of science teaching.

The findings of our study also highlight the change in the affective dimension of possible selves. During the science method course, the hoped-for self of shaking off prejudiced beliefs was changed to passing on a positive attitude. Furthermore, the wish to pass on a 
positive attitude changed to the desire to be inspiring and pass on interest during the teaching practicum. These changes in the affective hoped-for selves were balanced against changes in the feared selves, including the change from accidentally passing on the attitude to others to the fear of depreciate these subjects. Unlike the findings of Hong and Greene (2011), the affective possible selves in our findings were strictly personal, representing PSTs' wish to change their own beliefs regarding the subjects of biology and geography. Also, in our findings, the affective possible selves seemed to change because of intrapersonal reasons, rather than reasons like the relationships or cooperation between teachers, as suggested by Hamman et al. (2013a). Interestingly, what our findings revealed is that the changes identified were quite radical. The possible selves shifted from one extreme to the other. For example, we identified the change from reluctant beliefs to embracing the idea of being an inspiring teacher. In science teacher education, acknowledging PSTs' strong intrapersonal motivation for change can be beneficial when considering how to assist PSTs' in the change.

Another interesting finding is an enduring possible self that did not change at all. The resilience of being an inspiring teacher, accompanied by the wish to be interested and an interesting teacher, remained the same and unaffected by the course or the teaching practicum. This hoped-for possible self was strongly built upon memories of the ideal teacher. The studies on belief change, clearly bring forth the idea that disequilibrium in experiences is required to induce change (Higgins 1987; Pajares 1992). Our findings, however, revealed that this disequilibrium was diminished during the teaching practicum, due to received positive feedback related to PSTs' interest towards biology and geography. The positive feedback seemed to close the gap between PST's actual and her ideal possible self-being like an ideal teacher from the past. This seems to have further signalled to the PST that there was no need for change (Oyserman and Leah 2011). We 
acknowledge that this hoped-for possible self refers to very positive outcomes and reflects a positive characteristic of a science teacher, however, it shows that the process of science teacher identity might include only a limited repertoire of possible selves. Therefore, we suggest that the resilience of some possible selves might also indicate the narrowing of the possible selves repertoire.

Our findings indicate the significance of possible selves for research on pre-service primary teachers' identity development in the context of science teaching and, especially for assisting this process. Moreover, the findings have demonstrated that the changes can occur as a result of a single course and teaching practicum and that the process of change is not necessarily linear and steady, which makes the examination of possible selves at different time points especially important. That said, we acknowledge that this is a smallscale study and its findings can't be generalized. Based on our experiences as teacher educators, however, we see that the cases addressed here are rather typical (Patton 1990), which means that teacher educators can identify similar PSTs and the changes they undergo in their possible selves in their courses. In addition, the PSTs' narratives in this study provide a profuse description regarding their possible selves and the changes in this process, thus allowing teacher educators to evaluate themselves how trustworthy these narratives are.

We thus see that this study brings forth important implications for teacher education. First, possible selves should be carefully considered in primary teacher education regarding teaching of various subjects in order to give PSTs a possibility for reflection upon their own socio-historical pasts (Avraamidou 2019; Carrier 2017; Furlong 2013), in order to support the change in their beliefs (Pajares 1992) and in order to make them reflect upon the future requirements and needs (Woolhouse and Cochrane 2015). All these aspects, arguably, are involved in the process of teacher identity development in the 
context of science teaching and in the context of teaching other subjects. Second, in addition to Hong and Greene's (2011) suggestion that science teacher education should ensure that PSTs are enabled to build their content knowledge, we further suggest that science teacher education should ensure that PSTs understand the significance of deepening their content knowledge instead of just broadening it. Third, the change in possible selves can be valuable for assessing PSTs' knowledge and development of their reflective skills, and the change can also show the extremes in the process of science teacher identity development. Because some possible selves can also remain unchangeable, which may imply the scarce repertoire of possible selves, teacher educators should provide the opportunities for widening this repertoire. Teacher educators should also bear in mind that even if they provide for PSTs valuable experiences that can change PSTs' possible selves as science teachers, they may also unknowingly support the thought that no actions or changes are required. For this reason, we conclude with the hope that the articulation of possible selves and the discussion about how to achieve or avoid those becomes a part of the teacher education pedagogies in order to support PSTs' identity development. 


\section{References}

Avraamidou, L. 2014. "Studying Science Teacher Identity: Current Insights and Future Research Directions." Studies in Science Education 50 (2): 145-179. doi: $10.1080 / 03057267.2014 .937171$

Avraamidou, L. 2019. "Stories We Live, Identities We Build: How Are Elementary Teachers' Science Identities Shaped by Their Lived Experiences?” Cultural Studies of Science Education 14 (1): 33-59. doi: 10.1007/s11422-017-9855-8

Beijaard, D., P. C. Meijer, and N. Verloop. 2004. "Reconsidering Research on Teachers' Professional Identity." Teaching and Teacher Education 20 (2): 107-128. doi: 10.1016/j.tate.2003.07.001

Brady, I. K. 2019. "Possible Teaching Selves: The Challenges of Becoming a Bilingual Teacher.” International Journal of Applied Linguistics and English Literature, 8 (2): 145-154. doi: 10.7575/aiac.ijalel.v.8n.2p.145

Bryce, N., Wilmes, S. E., and Bellino, M. 2016. "Inquiry identity and science teacher professional development." Cultural Studies of Science Education, 11 (2): 235251. doi: $10.1007 / \mathrm{s} 11422-015-9725-1$

Carrier, S. J., A. N. Whitehead, T. A. Walkowiak, S. C. Luginbuhl, and M. M. Thomson. 2017. "The Development of Elementary Teacher Identities as Teachers of Science.” International Journal of Science Education 39 (13): 1733-1754. doi: $10.1080 / 09500693.2017 .1351648$

Carroll, P. J., J. A. Shepperd, and R. M. Arkin. 2009. “Downward Self-Revision: Erasing Possible Selves.” Social Cognition 27 (4): 550-578. doi: $10.1521 /$ soco.2009.27.4.550 
Clandinin, D. J., and F. M. Connelly. 2000. "Narrative Inquiry." San Francisco, CA: Jossey-Bass.

Clarke, D., and Hollingsworth, H. 2002. "Elaborating a model of teacher professional growth." Teaching and teacher education, 18 (8): 947-967. doi: 10.1016/S0742051X(02)00053-7

Cohen, L., L. Manion, and K. Morrison. 2002. "Research Methods in Education." Routledge, London and New York.

Conway, P. F., and C. M. Clark. 2003. "The Journey Inward and Outward: A ReExamination of Fuller's Concerns-Based Model of Teacher Development.” Teaching and Teacher Education 19 (5): 465-482. doi: 10.1016/S0742051X(03)00046-5

Cross, S., and H. Markus. 1991. "Possible Selves Across the Life Span." Human Development 34 (4): 230-255. doi: 10.1159/000277058

Dabback, W. 2017. “A longitudinal perspective of early career music teachers: Contexts, interactions, and possible selves.” Journal of Music Teacher Education, 27 (2): 52-66. https://doi.org/10.1177/1057083717727268

Darling-Hammond, L., Hyler, M. E., Gardner, M. 2017. “Effective Teacher Professional Development." Learning Policy Institute, Palo Alto, CA.

Flores, M. A. 2020. "Feeling Like a Student but Thinking Like a Teacher: A Study of the Development of Professional Identity in Initial teacher education.” Journal of Education for Teaching, 46 (2): 145-158. doi: 10.1080/02607476.2020.1724659 
Furlong, C. 2013. "The Teacher I Wish to Be: Exploring the Influence of Life Histories on Student Teacher Idealised Identities." European Journal of Teacher Education 36 (1): 68-83. doi: 10.1080/02619768.2012.678486

Gunning, A. M., and Mensah, F. M. 2011. "Preservice elementary teachers' development of self-efficacy and confidence to teach science: A case study." Journal of Science Teacher Education, 22: 171-185. doi: 10.1007/s10972-010-9198-8

Hamman, D., K. Gosselin, J. Romano, and R. Bunuan. 2010. "Using Possible-Selves Theory to Understand the Identity Development of New Teachers.” Teaching and Teacher Education 26 (7): 1349-1361. doi: 10.1016/j.tate.2010.03.005

Hamman, D., F. Coward, L. Johnson, M. Lambert, L. Zhou, and J. Indiatsi. 2013a. "Teacher Possible Selves: How Thinking About the Future Contributes to the Formation of Professional Identity." Self and Identity 12 (3): 307-336. doi: $10.1080 / 15298868.2012 .671955$

Hamman, D., E. Wang, and H. Burley. 2013b. "What I Expect and Fear Next Year: Measuring New Teachers' Possible Selves.” Journal of Education for Teaching 39 (2): 222-234. doi: 10.1080/02607476.2013.765194

Henry, A. 2015. "The Dynamics of Possible Selves." In Motivational Dynamics in Language Learning, edited by A. Henry, Z. Dörnyei, and P. D. Macintyre, 83-94. Multilingual Matters, Bristol.

Higgins, E. T. 1987. "Self-Discrepancy: A Theory Relating Self and Affect." Psychological Review 94 (3): 319. 
Hong, J., and B. Greene. 2011. "Hopes and Fears for Science Teaching: The Possible Selves of Preservice Teachers in a Science Education Program." Journal of Science Teacher Education 22 (6): 491-512. doi: 10.1007/s10972-011-9247-y

Ibarra, H. 1999. "Provisional Selves: Experimenting with Image and Identity in Professional Adaptation." Administrative Science Quarterly 44: 764-791. doi: $10.2307 / 2667055$

Kaasila, R. (2007). Using narrative inquiry for investigating the becoming of a mathematics teacher. ZDM 39 (3): 205-213. doi: 10.1007/s11858-007-0023-6

Kaasila, R., and Lauriala, A. 2010. Towards a collaborative, interactionist model of teacher change. Teaching and Teacher Education 26 (4): 854-862. doi: 10.1016/j.tate.2009.10.023

Korthagen, F. 2017. "Inconvenient Truths About Teacher Learning: Towards Professional Development 3.0." Teachers and Teaching 23 (4): 387-405. doi: $10.1080 / 13540602.2016 .1211523$

Lieblich, A., R. Tuval-Mashiach, and T. Zilber. 1998. "Narrative Research: Reading, Analysis, and Interpretation” (Vol. 47). Sage Publications, London.

Lutovac, S., and Kaasila, R. 2012. Dialogue between past and future mathematical identities. Nordic Studies in Mathematics Education 17 (3-4): 125-139.

Lutovac, S., and Kaasila, R. 2014. Pre-service teachers' future-oriented mathematical identity work. Educational Studies in Mathematics 85 (1): 129-142. doi: $10.1007 / \mathrm{s} 10649-013-9500-8$

Markus, H., and P. Nurius. 1986. “Possible Selves.” American Psychologist 41 (9): 954. 
Mensah, F. M. 2016. "Positional identity as a framework to studying science teacher identity: Looking at the experiences of teachers of color." In Studying science teacher identity, edited by L. Avraamidou, pp. 49-69. Sense Publishers, Rotterdam, The Netherlands.

Naidoo, K. 2017. "Capturing the Transformation and Dynamic Nature of an Elementary Teacher Candidate's Identity Development as a Teacher of Science." Research in Science Education 47 (6): 1331-1355. doi: 10.1007/s11165-016-9550-x

Oyserman, D., D. Bybee, K. Terry, and T. Hart-Johnson. 2004. "Possible Selves as Roadmaps." Journal of Research in Personality 38 (2): 130-149. doi: $10.1016 / \mathrm{S} 0092-6566(03) 00057-6$

Oyserman, D., D. Bybee, and K. Terry. 2006. "Possible Selves and Academic Outcomes: How and When Possible Selves Impel Action.” Journal of Personality and Social Psychology 91 (1): 188. doi: 10.1037/0022-3514.91.1.188

Oyserman, D., and L. James. 2011. “Possible Identities.” In Handbook of Identity Theory and Research, edited by S. J. Schwartz, K. Luyckx, V. L. Vignoles, 117-145. Springer, New York. doi: 10.1007/978-1-4419-7988-9.pdf

Oyserman, D., and H. Markus. 1990. "Possible Selves in Balance: Implications for Delinquency." Journal of Social Issues 46 (2): 141-157. doi: 10.1111/j.15404560.1990.tb01927.x

Pellikka, A., Lutovac, S., and Kaasila, R. (2018). The nature of the relation between preservice teachers' views of an ideal teacher and their positive memories of biology and geography teachers. Nordic Studies in Science Education 14 (1): 82-94. doi: $10.5617 /$ nordina. 4368 
Patton, M. 1990. "Qualitative evaluation and research methods." Sage, Thousand Oaks.

Polkinghorne, D. E. 1995. "Narrative Configuration in Qualitative Analysis." International Journal of Qualitative Studies in Education 8 (1): 5-23. doi: $10.1080 / 0951839950080103$

Ronfeldt, M., and Grossman, P. 2008. "Becoming a professional: Experimenting with possible selves in professional preparation." Teacher Education Quarterly, 35 (3): $41-60$.

Ruohotie-Lyhty, M., and Kaikkonen, P. 2009. "The difficulty of change: The impact of personal school experience and teacher education on the work of beginning language teachers." Scandinavian Journal of Educational Research, 53 (3): 295309. doi: $10.1080 / 00313830902917378$

Tam, A. C. F. 2015. "The Role of a Professional Learning Community in Teacher Change: A Perspective from Beliefs and Practices.” Teachers and Teaching 21 (1): 22-43. doi: 10.1080/13540602.2014.928122

Urzúa, A., and Vásquez, C. 2008. "Reflection and professional identity in teachers' future-oriented discourse." Teaching and teacher education, 24 (7): 1935-1946. doi: $10.1016 /$ j.tate 2008.04 .008

Woods-McConney, A., M. Wosnitza, and K. L. Sturrock. 2016. "Inquiry and Groups: Student Interactions in Cooperative Inquiry-Based Science." International Journal of Science Education $38 \quad$ (5): $\quad 842-860$. doi:10.1080/09500693.2016.116945.

Woolhouse, C., and Cochrane, M. 2015. "Educational policy or practice? Traversing the conceptual divide between subject knowledge, pedagogy and teacher identity in 
England." European Journal of Teacher Education, 38 (1): 87-101. doi: $10.1080 / 02619768.2014 .921154$ 


\section{Appendix 1.}

Questionnaire 1. (At the beginning of ES course)

1. What kind of memories do you have from science lessons and teachers from your time at school?

2. How would you describe yourself as a teacher of science?

3. What kind of teacher of science you would like to be?

Interview 1. (At the beginning of ES course)

1. Memories

a) Tell more about your science teachers from your time at school.

b) What memory related to science teaching and learning from your time at school is the most significant for you as a future teacher?

2. As a teacher in the future

a) Tell what kind of teacher of science you would like to be in the future?

b) What kind of teacher of these subjects you would not like to be?

Questionnaire 2. (After the ES course)

1. What was the most significant learning experience for you as a future teacher of science during the course?

2. How would you describe yourself as a teacher of science now?

3. Tell what kind of teacher of science you would like to be in the future?

Interview 2. (After the ES course)

1. Experiences from the course

a) How did your views about teaching and learning science changed during the course?

b) Tell what was challenging for you?

2. As a future teacher

a) Tell how would you describe yourself as a teacher of science now?

b) Tell what kind of teacher of science you would like to be in the future?

c) What kind of teacher of science you would not like to be? 

d) Tell what kind of goals you would set for yourself now as a future teacher of science?

Interview 3. (After teaching practicum, 2 years after ES course)

1. Experiences from the teaching practicum

a) Tell what were the most significant experiences for you as a science teacher in the practicum?

b) Tell did your views of teaching science change during the practicum?

2. As a future teacher
a) Tell how would you describe yourself as a teacher of science now?
b) Tell what kind of teacher of science you would like to be in the future?
c) Tell did your views of yourself as a science teacher change during the practicum?
d) Tell what kind of goals you would set for yourself as a future science teacher? 


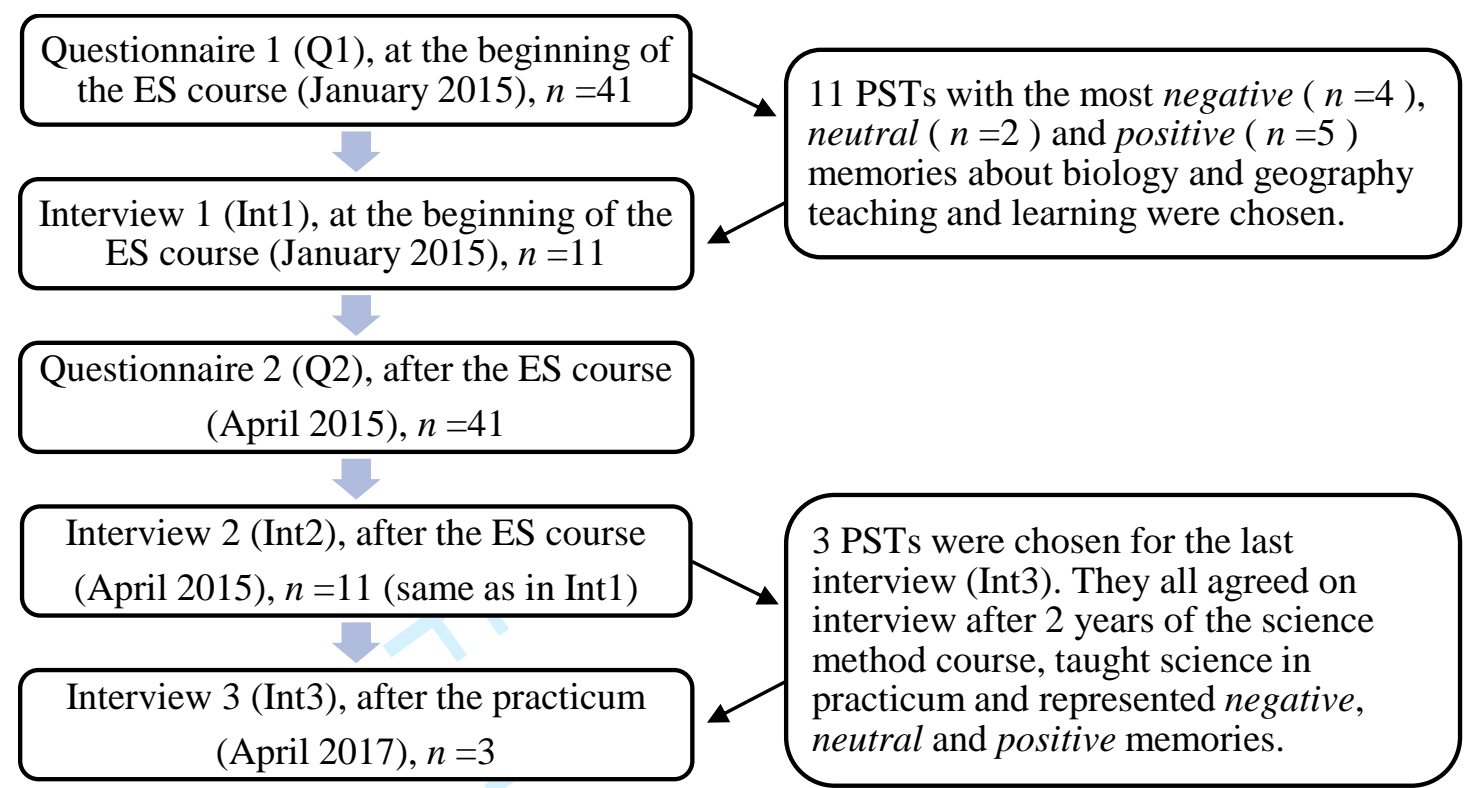

Figure 1. Data collection procedure. 